Madrygal. Revista de Estudios Gallegos

ISSN: 1138-9664

\title{
Doce poemas de vello
}

Manuel Forcadela

\author{
I. Louis Althusser \\ O importante deste home \\ é que non ten importancia, \\ que sabe que non sabe onde está \\ e que precisa algures para ir. \\ —De onde chegas, forasteiro? \\ -De lonxe.
}

II.

E sendo numerosas as obras e traballos

Que deben adornar a vida anacoreta

E moitas as obrigas, enredos e misións

Que impón a agricultura e o culto do xardín,

Non son, así, menores aquelas que require

Das rosas o labor, das silvas o combate

III.

E quen nos vai valer, Terra de Montes?

Quen mirará por nós, xardín do esquecemento?

Quen virá nos gorentar, viño do olvido?

IV.

Faite vello. Prevalece

Sobre os tempos anteriores. Non difundas

Os dominios doutra idade. E alimenta

Os imperios do saber. Da beleza,

Se cabe, máis devoto.

E faino todo devagar.

Tranquilamente. 
V.

Herba do aire,

herba do mar,

nenúfar e ninfea

de grandes follas,

floreada

de branco e de amarelo,

tamén a ti pertenzo,

aire da araña e mal de ollo,

cálice sagrado do viño e do fermento

da uva polo sangue,

do tempo,

sucesión

das cousas como un ciclo,

das horas como partes

da idade e da existencia,

a ti, como estación dos barcos que atravesan

os mares como un treito da noite

e da distancia,

o tempo inda varrendo o po destes altares,

a foula e a muíña das ceas sobre a mesa,

baixada esta persiana

que filtra a claridade

da lúa sobre as teclas do piano,

divina hortensia embriagadora

da luz de medianoite,

da noite cos seus hábitos de voda,

esponsal da escuridade

sen vestido

nupcial,

do tálamo

con máscaras escuras,

as dúas apalpando

o pálpito da sombra,

a noite,

a media noite.

VI.

E cumprirás o teu destino de ruína

E serás corpo canso,

Esp'ranza derrotada,

Espello do fracaso,

Unha borra que ficou do viño consumido, 
Da cera derretida,

Un vestixio,

Refugallo

Dun antigo vivir,

Desperdicio,

Varredura.

VII.

Venderei a miña alma

A quen me dea tres castelos:

Un para os menceres e a mañá,

Outro para as tardes e o solpor,

E o máis difícil, derradeiro,

Aquel para as noitadas de invernía.

Non precisan ser moi grandes.

Mesmo abonda

Con que teñan unha torre, unha bandeira,

Unha ponte levadiza.

VIII.

Estes ollos non encontran acomodo.

Nin quietude, nin letargo, nin sopor

Dan amparo ao seu afán,

Sosego ao seu tumulto.

Pola noite nas raíces do rostro

Hai enxamio e fervedoiros

A empurrárenme a pel,

A alongárenme as pregas,

Estas minguas e curvas

Como froito dos anos,

O debuxo que trazaron as idades.

Son as néboas dos camiños percorridos.

Son as lamas doutras chuvias e poeiras.

Son o son doutras galernas.

Non hai rostro verdadeiro.

Todo esconde o que lle pasa. 
IX.

Prendo agora nesta aperta

Aquel neno que fun.

É abrazo de aloumiño,

Un aceno de reunión,

Un amparo, un acubillo.

Suxeito ese suxeito que crecía,

Semente a esparexer brotes e canos,

Cadullos e cardos, coios e terróns,

E abrázome aceptándoo.

Ben sei que mesmo apreixo

Aquel que inda non era

E o que logo non foi.

Substancia do posible e do imposible.

Regreso deste xeito ao vello neno.

Ingresa para sempre o neno vello.

X.

Divina hortensia embriagadora

da luz de medianoite,

cálice sagrado do viño e do fermento

das uvas polo sangue,

herba do aire,

herba do mar,

nenúfar e ninfea

de grandes follas, floreada

de branco e de amarelo,

e quen nos vai valer, Terra de Montes?

Quen mirará por nós, xardín do esquecemento?

Quen virá nos gorentar, viño do olvido?

XI.

Dos nomes que habitei

No curso dos meus anos,

Nomes como casas, residencias,

Albergues, campamentos,

Foron músico e poeta aqueles que acolleron

Con grandes agarimos e bondades

Os corpos desolados. 
O músico que viña da estirpe e da raíz,

Poeta como asombro e ladaíña.

Músicos aqueles que senten devalar

O tempo como un sopro, o pálpito, o bater

Do espazo contra a caixa do misterio.

Poetas os que chegan de noite a unha lanterna

e dan en acender os días derrubados.

XII.

Longos anos trasladei o meu corpo por ocasos

Por tormentas e venturas

Procurando un non sei que de lugares e horizontes.

Era algo sen obxecto,

Unha especie de substancia,

A chamada radical da raíz ou do destino.

E así celebro agora o rito do lugar,

O cántico da nube e da presenza,

Da herba que acariña as plantas dos meus pés,

Dos froitos que apodrecen pola terra,

E teimo en entregarme á chuvia que se achega,

Ao círculo e ao ciclo,

Á roda na que xiran os imperios do tempo.

E é na luz que lle abre paso

Á beleza da ruína

Onde viven amparadas

A piedade, a compaixón,

Oh bébeda de hortensias e flor de laranxeira. 